Vol. 2 No.2 Juni 2019

http://jurnal.umsb.ac.id/index.php/RANGTEKNIKJOURNAL

\title{
EVALUASI STRUKTUR BALOK LANTAI 2 PADA PROYEK PEMBANGUNAN GEDUNG RUMAH SAKIT UMUM DAERAH (RSUD) dr. RASHIDIN PADANG PROVINSI SUMATERA BARAT
}

\author{
Arman. A ${ }^{1,}$ Rendi Mai Jasman ${ }^{2}$ \\ Jurusan Teknik Sipil ITP, Mahasiswa Jurusan Teknik Sipil ITP ${ }^{2}$ \\ arman.agung@yahoo.com ${ }^{1}$, herix_sonata@yahoo.com ${ }^{2}$ \\ DOI: http://dx.doi.org/10.31869/rtj.v2i2.1328
}

\begin{abstract}
Abstrak: Beton merupakan salah satu pilihan sebagai bahan struktur dalam kontruksi bangunan. Inovasi teknologi beton selalu dituntut guna menjawab tantangan akan kebutuhan, beton yang dihasilkan diharapkan mempunyai kwalitas tinggi meliputi kekuatan dalam daya tahan tanpa mengabaikan nilai ekonomis. Peraturan mengenai standar spesifikasi agregat di indonesia mengalami perubahan seiring dikeluarkannya SNI 7656-2012 dan ASTM C 136-06 yang mengenai persyaratan Spesifikasi agregat untuk perencanaan beton. Salah satu hal baru yang tercantum dalam SNI 76562012 adalah dalam hal penentuan gradasi saringan di tetapkan dalam zona-zona yang telah di tentukan, hal ini sedikit berbeda dari peraturan ASTM C 136-06 yang menyatakan bahwa spesifiksi gradasi telah di tentukan.Penelitian ini bersifat eksperiment yang dilaksanakan dilaboratorium teknik sipil Institut Teknologi Padang (ITP).Objek pada penelitian ini adalah beton dengan mutu sedang yang menggunakan bahan Standar SNI 7656-2012 dan ASTM C 136-06. Pembuatan benda uji yang digunakan berbentuk kubus berukuran lebar $15 \mathrm{~mm}$ x tinggi $15 \mathrm{~mm}$ x Panjang $15 \mathrm{~mm}$. Sebanyak (3) sampel tiap variasi campuran yang berbeda dengan umur beton 7,14,dan 28 hari. Rata - rata nilai pengujian kuat tekan beton kubus umur 7 hari degan suhu air $25^{\circ} \mathrm{C}$ proses pengerjaan pada pagi hari Standar SNI 7656-2012 sebesar 171,55Kg/m² dan Standar ASTM C 136-06 sebesar 166,72 Kg/m² dengan persen perbandingan kuat tekan sebesar 3\%. Sementara pada benda uji kubus umur 14 hari dengan suhu air $28^{\circ} \mathrm{C}$ proses pengerjaan pada siang hari Standar SNI 7656-2012 sebesar 222,30 $\mathrm{Kg} / \mathrm{m}^{2}$ dan Standar ASTM C 136-06 sebesar $210,22 \mathrm{Kg} / \mathrm{m}^{2}$ dengan persen perbandingan kuat tekan sebesar 5\%. Setelah dilakukan pembuatan benda uji dengan suhu air $25{ }^{\circ} \mathrm{C}$ langsung perawaatan benda uji, kubus umur 28 hari mengalami peningkatan kuat tekan beton peroleh nilai Standar SNI 7656-2012 sebesar 267,60 Kg/m² dan Standar ASTM C 136-06 sebesar 264,58 Kg/m² dengan persen perbandingan kuat tekan sebesar $1 \%$.

Berdasarkananalisisdanpembahasandapatdisimpulkanbahwa Job Mix Design beton metode ASTM C 136-06 menghasilkan proporsicampuran bahan yang relative lebih efisiendibandingkan metode SNI 7656-2012. Artinyabahwasecarateoritis Job Mix Design beton fc' 20.75Mpa metode ASTM C 136-06 lebih ekonomis dari segi penggunaan bahan dari metode SNI 7656-2012.
\end{abstract}

kata kunci: Metode SNI 7656-2012, ASTM C 136-06, Beton Normal, Kuat Tekan Beton.

\section{PENDAHULUAN}

Tinjauan struktur bangunan bertujuan untuk memperoleh suatu struktur yang cukup kuat dan aman, baik terhadap beban yang dipikul atau terhadap pengaruh luar yang mengenai struktur tersebut. Oleh sebab itu keberadaanya harus bisa menjamin bahwa secara struktur kuat atau mampu melayani keberadaan dan aktivitas penghuni atau penggunanya. Keberadaan bangunan harus sesuai dengan yang diharapkan oleh si pemilik (owner) dan tidak lepas dari peran perencana selaku yang merencanakan.

Secara garis besar proses perencanaan dapat dibedakan menjadi dua bagian. Tahap pertama adalah perencanaan umum yang merupakan peninjauan secara garis besar seperti tipe struktur, tata letak struktur, geometri atau bentuk bangunan, jarak antar kolom, tinggi lantai, dan material yang di gunakan untuk bangunan. Tahap kedua adalah mengenai perencanaan terinci yaitu perencanaan untuk menentukan dimensi kolom, balok, plat lantai dan elemen struktur lainnya. Kedua tahap perencanaan tersebut saling mengait satu sama lain sehingga bangunan tersebut mempunyai kekuatan yang cukup dan memiliki fungsi tersendiri sesuai dengan bangunan tersebut. 
Namun kekuatan yang cukup dimiliki oleh suatu bangunan adalah apabila bangunan tersebut dapat menahan dan memikul beban puncak selama usia bangunan (life of service). Dalam struktur beton bertulang, kekuatan elemen struktur kolom, balok dan plat lantai dibatasi oleh kapasitas atau kemampuan penampang dalam menahan momen maksimum. Sedangkan kapasitas penampang di pengaruhi oleh dimensi penampang, jumlah dan diameter tulangan, mutu material dan penjangkaran. Unsur yang juga penting dan berkaitan dengan kekuatan struktur adalah daktilitas. Struktur harus memiliki prilaku dalam menahan beban-beban luar, terutama struktur yang di rencanakan untuk menahan beban gempa.

Tinjauan Struktur Pada Pembangunan Fisik Gedung Rumah Sakit Umum Daerah (RSUD) dr. Rashidin Padang ini diharapkan dapat menciptakan struktur yang kuat dan mampu melayani segala aktifitas pada konstruksi gedung tersebut nantinya. Bangunan ini memakai konstruksi beton bertulang menurut standar yang berlaku di Indonesia.

\section{TINJAUAN PUSTAKA Beton Bertulang}

Beton adalah campuran antara semen Portland atau semen hidraulik lainnya, agregat halus, agregat kasar, dan air, dengan atau tanpa bahan tambahan yang membentuk masa padat (SNI-03-2847-2012, Pasal 3.12).

Beton bertulang adalah beton yang ditulangi dengan luas dan jumlah tulangan yang tidak kurang dari nilai minimum yang di syaratkan dengan atau tanpa prategang, dan direncanakan berdasarkan asumsi bahwa kedua bahan tersebut bekerja sama dalam memikul gaya-gaya. (SNI-03-2847-2002, Pasal 3.13).

\section{Stuktur Balok Beton Bertulang}

Balok adalah bagian dari struktural sebuah bangunan yang kaku dan dirancang untuk menanggung dan mentransfer beban menuju elemen-elemen kolom penopang. Selain itu ring balok juga berfungsi sebagai pengikat kolomkolom agar apabila terjadi pergerakan kolomkolom tersebut tetap bersatu padu mempertahankan bentuk dan posisinya semula. Beberapa jenis balok beton antara lain:

a. Balok sederhana bertumpu pada kolom diujung-ujungnya, dengan satu ujung bebas berotasi dan tidak memiliki momen tahan.

b. Kantilever adalah balok yang diproyeksikan atau struktur kaku lainnya didukung hanya pada satu ujung tetap.

c. Balok teritisan adalah balok sederhana yang memanjang melewati salah satu kolom tumpuannya.

d. Balok bentangan tersuspensi adalah balok sederhana yang ditopang oleh teristisan dari dua bentang dengan konstruksi sambungan pin pada momen nol.

e. Balok kontiniu adalah balok yang memanjang secara menerus melewati lebih dari dua kolom tumpuan untuk menghasilkan kekakuan yang lebih besar dan momen yang lebih kecil dari serangkaian balok tidak menerus dengan panjang dan beban yang sama.

\section{Pembebanan Struktur \\ Beban Balok}

Penentuan beban yang bekerja pada struktur atau elemen struktur secara tepat tidak selalu dapat dilakukan, walaupun lokasi beban pada struktur diketahui. Beberapa jenis beban yang paling umum adalah:

a. Beban Mati (Dead Load)

Beban mati adalah beban yang ditimbulkan oleh berat dan berbagai komponen bangunan itu sendiri dan termasuk berat kerangka.

b. Beban Hidup (Live Load)

Beban hidup adalah setiap beban yang harus diangkut oleh komponen bangunan dan ditinjau sebagai beban transien, yakni beban tersebut dapat dipakaikan untuk beberapa jam sampai beberapa tahun, tetapi besarnya berubah-ubah.

c. Beban Gempa (Earth Quake Load)

Beban gempa adalah beban yang muncul akibat pengaruh pergerakan dalam arah mendatar atau vertikal yang disebabkan oleh gempa. Definisi lain dari beban gempa adalah semua beban statik ekivalen yang bekerja pada gedung atau bagian gedung yang menirukan pengaruh dari gerakan tanah akibat gempa.

Beban Gempa (SNI 1726-2012)

$\begin{array}{lr}\text { Fakultas Teknik UMSB } & \text { ISSN 2599-2081 } \\ \text { EISSN 2599-2090 }\end{array}$


Perhitungan beban geser dasar total dan distribusinya sepanjang tinggi gedung akibat gempa menurut peraturan SNI-1726-2012, langkah-langkahnya yaitu:

a. Beban Statik Eqivalen

Yaitu analisis beban statik horizontal untuk menirukan pengaruh gempa yang sesungguhnya akibat gerakan tanah.

b. Koefisien Gempa Dasar (C)

Koefisien gempa dasar harus ditentukan berdasarkan wilayah dimana gedung itu di dirikan. Jika suatu gedung terletak pada suatu batas wilayah yang kepastian wilayahnya tidak jelas, gedung itu dianggap terletak didalam yang masyarakatnya nilai koefisien gempa dasar yang lebih besar.

c. Faktor Keutamaan (I)

Faktor keutamaan adalah suatu koefisien yang diadakan untuk memperpanjang waktu ulang dari kerusakan struktur struktur gedung. Gedung yang dimaksudkan adalah gedung monumenral atau gedung yang menyediakan fasilitas fasilitas yang harus tetap berfungsi setelah gempa terjadi.

d. Menentukan Kategori Resiko Nilai

e. Menentukan Faktor Keutamaan

f. Kombinasi Beban Terfaktor

g. Menentukan Nilai Spektra Percepatan Tanah $\left(\mathrm{S}_{\mathrm{s}}\right.$ dan $\left.\mathrm{S}_{1}\right)$

Dimana, $\mathrm{Sss}=$ Percepatan tanah dasar waktu pendek, dan S1= Percepatan tanah dasar waktu 1 detik. Untuk percepatan gempa $S_{s}$ dan $S_{1}$ berdasarkan jenis tanah dan lokasi bangunan dapat dilihat melalui website:

http//puskim.pu.go.id/aplikasi/desain_spek tra_indonesia_2011.

h. Menentukan Klasifikasi Situs

i. Koefisien Situs, Fa dan Fv

j. Parameter Percepatan Spektral Desain

k. Spektrum Respon Desain

1. Menentukan kategori desain seismik

m. Kombinasi Sistem Perangkai Dalam Arah yang Berbeda

n. Menentukan Gaya Geser Dasar Gempa

o. Menentukan Periode Fundamental Pendekatan

p. Menghitung Distribusi Gaya Lateral Akibat Gempa

Gaya Pada Balok

ISSN 2599-2081

EISSN 2599-2090
Ada beberapa sebab retak pada struktur beton, yaitu retak akibat lentur/momen dan retak akibat geser. Adapun tipe-tipe retak pada struktur yaitu :

- Retak lentur murni (flexural cracle)

- Retak geser murni (shear cracle)

- Retak geser lentur (flexure shear cracle)

\section{Penampang Tulangan Rangkap}

Secara struktur, tulangan tekan ini diperlukan, antara lain, untuk:

a. Meningkatkan momen ketahanan penampang karena dimensi penampang yang terbatas.

b. Meningkatkan kapasitas rotasi penampang yang berkaitan dengan peningkatan daktilitas penampang.

c. Meningkatkan kekakuan penampang, sehingga dapat mengurangi defleksi struktur.

d. Dapat mencakup kemungkinan adanya momen yang berubah tanda. Gaya luar yang bekerja pada struktur tidaklah selalu tetap, misalnya beban horizontal akibat gempa dapat menyebabkan momenmomen internal berubah tanda.

\subsubsection{Kekuatan Geser dan Penulangan Geser Pada Balok \\ Balok dengan keruntuhan geser} umumnya tanpa adanya peringatan awal. Untuk perilaku kegagalan getas (brittle) ini, penampang harus dirancang cukup kuat untuk memikul beban geser luar rencana. Terdapat dua jenis sengkang yang digunakan yaitu sengkang vertical dan sengkang miring / tulangan miring. Diameter sengkang yang umum digunakan adalah $8-10-12 \mathrm{~mm}$.

\section{HASIL PENELITIAN DAN PEMBAHASAN \\ Evaluasi Perhitungan Balok \\ Perhitungan Percepatan Gempa dan Distribusinya}

a. Kategori resiko bangunan Berdasarkan SNI 1726 : 2012 pada tabel 1 bangunan ini digolongkan pada kategori resiko bangunan IV

b. Faktor kekuatan gempa

Berdasarkan SNI 1726 : 2012 pada tabel 2 nilai faktor keutamaan gempa yang di dapatkan adalah : Ic $=1,50$

c. Parameter percepatan tanah 
Ss $=1,398 \quad S_{1}=0,600$

d. Klasifikasi situs

Berdasarkan SNI 1726 : 2012 pada tabel 3 dapat digolongkan pada tipe situs SD (Tnah Sedang)

e. Koefisien situs Fa dan Fv

Berdasarkan SNI 1726 : 2012 pada tabel 4 koefisien situs, $\mathrm{Fa}=1,0$

Berdasarkan SNI $1726: 2012$ pada tabel 5 koefisien situs, $\mathrm{Fv}=1,5$

f. Parameter respons spektral percepatan gempa maksimum berdasarkan SNI 17262012 :

$\mathrm{S}_{\mathrm{MS}}=1,398 \quad \mathrm{~S}_{\mathrm{M} 1}=$

g. Parameter percepatan spektral desain berdasarkan SNI 1726-2012,

$\mathrm{S}_{\mathrm{DS}}=0,932 \quad \mathrm{~S}_{\mathrm{D} 1}=$ 0,600

h. Spektrum respon desain berdasarkan SNI 1726 - 2012:

$\mathrm{T}_{0}=0,129, \mathrm{Ts}=0,559, \mathrm{Sa}=0,373$

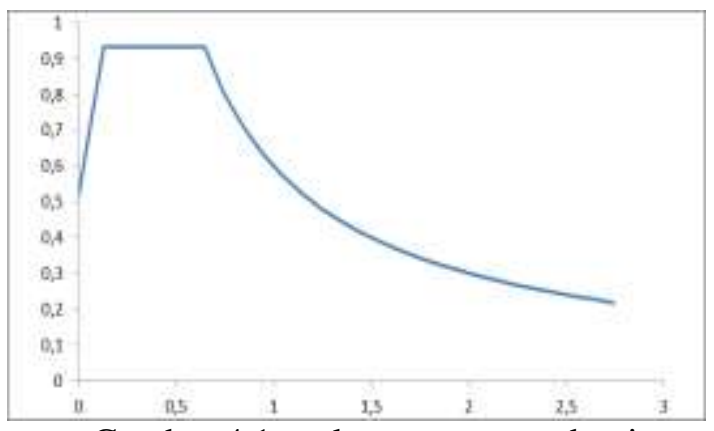

Gambar 4.1 spektrum respons desain

i. Kategori desain seismic

Berdasarkan SNI 1726:2012 Pada tabel 6, kategori desain seismik berdasarkan parameter respon percepatan pada perioda pendek $=\mathrm{D}$

Berdasarkan SNI 1726:2012 pada tabel 7, kategori desain seismik berdasarkan parameter respon percepatan pada perioda 1 detik = D

j. Sistem struktur

Berdasarkan SNI 1726 : 2012 tabel 8, sistem penahan gaya gempa yaitu rangka beton bertulang pemikul momen khusus

Koefisien modifikasi respons,

$$
\mathrm{R}^{\mathrm{a}}=>8
$$

Faktor kuat lebih sistem,

$$
\Omega_{0 \mathrm{~g}}=>3
$$

Faktor pembebanan defleksi,

$$
\mathrm{C}_{\mathrm{d}}{ }^{\mathrm{b}}=>5^{1} / 2
$$

Batasan sistem struktur dan batasan tingg struktur,

$$
\mathrm{h}_{\mathrm{n}}(\mathrm{m})^{\mathrm{c}}
$$

Kategori desain seismik $=>$ TB

\section{Perhitungan Pembebanan Bangunan}

Dari perhitungan, didapatkan berat total

\begin{tabular}{|c|c|c|c|}
\hline LANTAI & WD & WL & Wlantai \\
\hline 5 & 27.514 & 4.947 & 32.461 \\
\hline 4 & 42.648 & 4.947 & 47.595 \\
\hline 3 & 42.648 & 4.947 & 47.595 \\
\hline $1-2$ & 42.648 & 4.947 & 47.595 \\
\hline & & Wtotal & 175.246 \\
\hline
\end{tabular}
bangunan dan gambar gaya yang bekerja dapat dilihat pada tabel dibawah ini:

Tabel 1. Perhitungan berat total bangunan

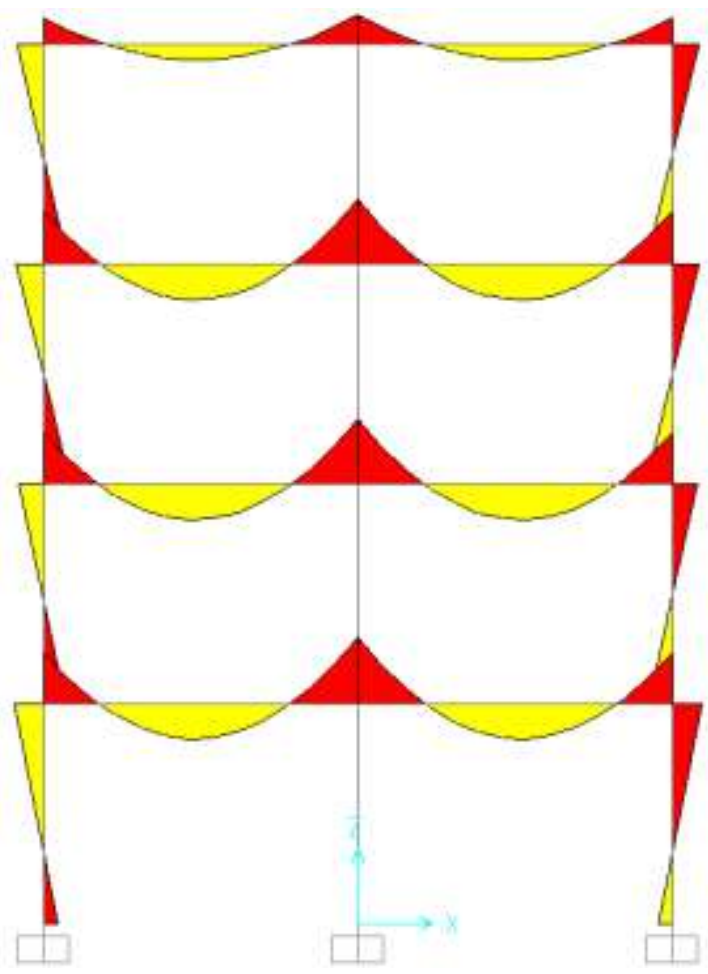

Gambar 1. Momen dan Gaya Geser 


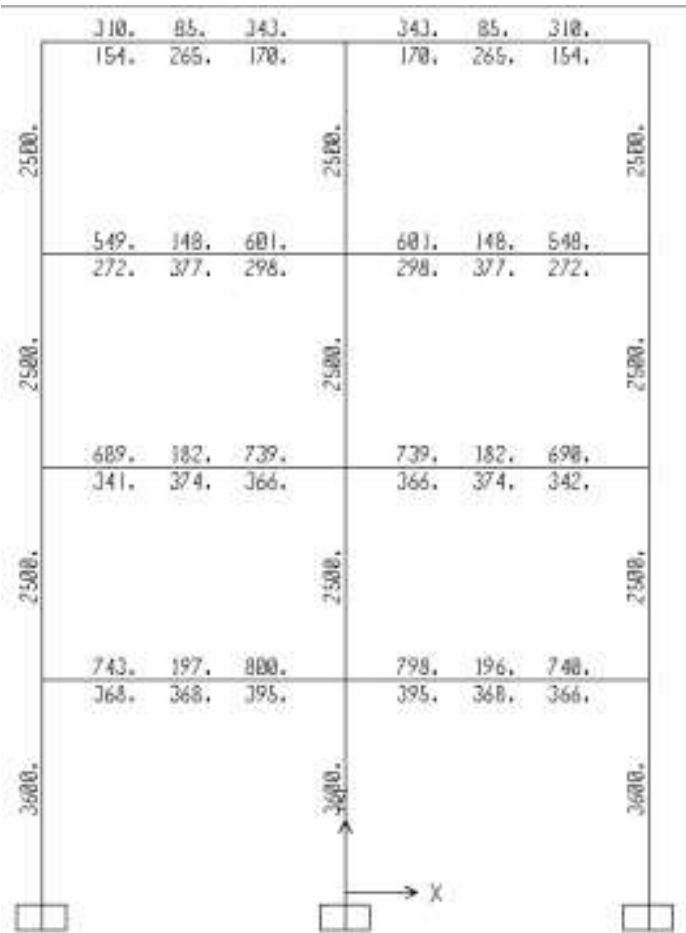

Gambar 2. Desain Luas Tulangan Logitudinal

Tabel 2. Perbandingan jumlah tulangan pokok

\begin{tabular}{|c|c|c|c|c|}
\hline $\begin{array}{c}\text { Balok B1/ } \\
\text { 40x60 }\end{array}$ & \multicolumn{2}{|c|}{ Manual } & \multicolumn{2}{c|}{ Program } \\
\cline { 2 - 5 } & Atas & Bawah & Atas & Bawah \\
\hline Tumpuan & 10D 19 & 7 D 19 & 7D 19 & 5 D 19 \\
\hline Lapangan & 7 D 19 & 10 D 19 & 5 D 19 & 7 D 19 \\
\hline
\end{tabular}

Lapangen 1 Turmpuan

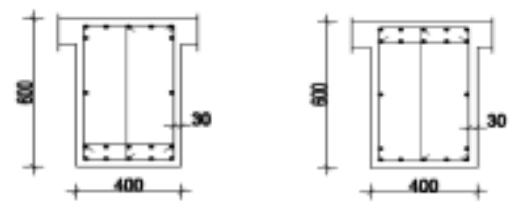

\begin{tabular}{c|c}
\hline $400 \times 600$ & $400 \times 600$ \\
\hline $7 D 19$ & $10 D 19$ \\
\hline $2 D 13$ & $2 D 13$ \\
\hline 10019 & 7019 \\
\hline$\$ 10-75$ & $10-50$ \\
\hline
\end{tabular}

Gambar 3. Gambar Eksisting Balok Lapangan dan Tumpuan

\section{PENUTUP}

Adapun kesimpulan yang dapat di ambil dari evaluasi struktur balok pada Pembangunan Gedung Rumah Sakit Umum Daerah (RSUD) dr. Rashidin Padang Sumatera Barat adalah:
1. Dari hasil perhitungan manual, Program dan berdasarkan gambar/lapangan, jumlah tulangan yang diperlukan relatif hampir sama atau tidak jauh perbadaan kebutuhan tulangan yang dihasilkan dari metode perhitungan yang digunakan tersebut.

2. Hasil dari evaluasi perhitungan analisa balok didapatkan jarak tulangan sengkang pada balok daerah lapangan dan tumpuan adalah D10-50, sehingga dapat disimpulkan perencanaan telah sesuai dengan SNI yang telah berlaku.

3. Hasil dari evaluasi perhitungan analisa balok jumlah tulangan tarik pada balok daerah tumpuan didapatkan 7D19 dan tekan pada balok daerah tumpuan didapatkan 10D19 telah dapat memikul beban pada balok, sehingga dapat disimpulkan bahwa jumlah tulangan tarik pada balok daerah tumpuan telah memenuhi syarat yang berlaku sesuai dengan perencanaan yang telah di tetapkan.

4. Hasil dari evaluasi perhitungan analisa balok didapatkan jumlah tulangan tarik pada balok daerah lapangan didapatkan 10D19 dan tekan pada balok daerah lapangan didapatkan 7D19 telah dapat memikul beban pada balok, sehingga dapat disimpulkan bahwa hasil dari perencaaan telah memenuhi syarat yang berlaku.

\section{DAFTAR PUSTAKA}

Badan Setandardisasi Nasional. (2013). Persyaratan Beton Struktural Untuk Bangunan Gedung SNI 2847:2013. Jakarta : BSN.

Agus Setiawan, ST, MT. (2007). Perancangan Struktur Beton Bertulang (Berdasarkan SNI 2847:2013). Jakarta : Erlangga.

Ir. Asiyanto, MBA (2014). Metode Bangunan Konstruksi Bertingkat. Jakarta : Gramedia.

Prima Yane Putri, ST, MT. (2016). Analisis dan Desain Struktur Rangka dengan SAP2000 Versi Student. Padang : UNP Press.

Sri Mulanto (2010). Analisis Struktur Bangunan dan Gedung dengan SAP2000 Versi 14. Yogyakarta : Andi Offset.

Musyaddat Khalil (2014). Evaluasi Struktur Pelat Lantai Gedung Layanan Pendidikan (Labskill Jurusan Kebidanan 
Gunung Pangilun) Politikes Kemenkes Padang. Padang: Proyek Akhir.

Trianto Kurniawan. (2016). Konstruksi Pelat Lantai. dari http://triantome dia blogspot.com/2011/01/konstruksi pelat lantai.html. Diakses pada tanggal 4 November 2016 pukul 17.32 WIB.

Ekhardi. (2016). Sistem Perletakan Pelat Lantai, dari http://ekhardhi. Blogspot. com/2010/ 12/sistem perletakan pelat lantai.html. Diakses pada tanggal 4 November 2016 pukul 20.17 WIB.

ITP. (26 Februari 2016). Pedoman Proyek Akhir. Padang : ITP.

Peraturan beton bertulang SNI 03-2847-2002.

Standar Nasional Indonesia. (2012). Tata Cara Perencanaan Ketahanan Gempa Untuk Struktur Bangunan Gedung Dan Non Gedung, SNI $1726: 2012$.

Standar Nasional Indonesia. (2013). Beban Minimum Untuk Perancangan Bangunan Gedung Dan Struktur Lain, SNI 1727 : 2013.

Agus, dan Syafri Wardi. (2013). Rekayasa Gempa. Yogyakarta : Andi.

Struktur Beton I \& II, Prof.DR Ir. Bambang Budiono,ME.

Analisa dan Desain Struktur Rangka dengan SAP2000 versi student Prima Yane Putri 